\title{
TEACHERS' COMMUNICATION STRATEGY IN SMA SWASTA PENCAWAN MEDAN
}

\author{
Helmida Barus \\ Universitas Prima Indonesia \\ Dorsita Sitohang \\ Universitas Prima Indonesia \\ Meyna Malango \\ Universitas Prima Indonesia \\ Seprosari Simbolon \\ Universitas Prima Indonesia \\ helmidabarus16@gmail.com
}

Submit, 13-12-2019 Accepted, 30-01-2020 Publish, 02-02-2020

\begin{abstract}
This study aims to discuss teacher communication strategies to students in improving student achievement. According to researchers obstacles what teachers face in improving student achievement is concerned free time or opportunity to gather (discuss) between the teacher and student. This research is a type of qualitative research, which researchers as the key instrument, from the interview results the researcher gave a picture of that teacher communication strategies in creasing student achievement in more schools to rewards, in reality teacher often misinterterpret strategies this, The teacher only understands the form of punishment given to students who guilty, even thought the reward should also be given to students who achievers in the form of gifts, praise and others. From the three studies above it can be concluded In the learning process still found 15 students from 30 students who have difficulty in communicating, so it is very influential in the participation and achievement of students learning. To solve the problem, it is by using a learning method that requires students to be actively communicating, dare to express opinions. The problem that is examined in this research is how the form of teacher communication with the students occurs
\end{abstract}

Keywords : communication strategies, English language learning. 


\section{INTRODUCTION}

Communication is to provide information, messages, ideas, thoughts and feelings to others with the intention that others participation in the eventual information. In a message delivery or idea during the communication process, it often happens a depreciation of communication that is realized by the teacher. In other words, in the process of delivering the message will be a matter of meaning that the material received by the students is almost not equal and may not correspond to the material submitted by the teacher. Such as, teachers are required to use communication strategies to minimize the occurrence of a depreciation of meaning. In communicating with others people need vocabulary. Vocabulary is also need in learning proses (Yenita, 2019).

Strategic competence or communication strategies' has become an important element of the communicative competence that a second or foreign language learner needs in order to communicate effectively (Canale \& Swain, 1980; Savignon 1983; Canale 1983; Bachman 1990; Celce-Murcia, Dörnyei \& Thurrell,1995; Ahmed \& Pawar, 2018). Some educators think that it is not necessary to teach strategic competence as a part of the language syllabus as learners already have acquired these strategies of communication from their mother tongue. However, the situation with a foreign language is completely different as learners need such strategies not only for making further meanings that are more sophisticated and diplomatic but to compensate for lack of linguistic or sociolinguistic competencies.

Carvantes \& Roddringuez (2012) studied CSs used by two EFL teachers and their beginner level students in Mexico City, and the potential factors that influence the communication strategy use in class. For the purpose of collecting data, the researchers used audio-recordings of naturally occurring classroom interactions, interviews with the teachers and observation field notes taken in six class sessions. Data from the interaction transcripts were examined as adapting Faerch \& Kasper's (1983) taxonomy of communication strategies as analysis basis. Results indicated that the most frequently used communication strategy in both groups was language switch. However, the teacher who seemed more involved with students used clarification request, comprehension check and asking for confirmation strategies. The teacher who appeared more distant from students used comprehension check and repetition strategies. Class size, seating arrangements and learning activity tasks were also some of the factors that influenced the communication strategies use.

The advantage of this research is that the description and interpretation of the informant can be examined in depth by the researcher. This research has a theoretical basis that fits the facts more subjectively. This research is very 
effective to be used in finding responses and views because of meeting directly with teachers and students.

\section{LITERATURE REVIEW}

In this section, the study is to survey the previous research on communication strategies. It attempts to go through the various definitions of communication strategies, categories of communication strategies, their significance in communication and language learning and providing some examples of most common communication strategies. (Sabri \& Sunil, 2018).

Communication in English is communication, derived from the common word or from the word comunis meaning "the same" or "the same meaning" in other words communication gives understanding together with the intention of changing thoughts, attitudes, behaviors, recipients and doing what is desired by the communicator. According to Roben Communication is a behavioral activity or the activity of delivering messages or information about thoughts or feelings. 18 Not far from Roben's understanding, John R. Schemerhorn in his book titled Managing Organizational Behavior states that communication can be interpreted as a process between individuals in sending and receiving symbols meaningful in their interests. $19 \mathrm{JL}$ Aranguren 20 in his book Human Communication states that communication is the transfer of communication to obtain responses. Meanwhile, Melvin L. De Fleur 21 defines communication as coordinating the meaning between a person and the audience. John C. Merril 22 said that communication is nothing but an adjustment of mind, the creation of a shared symbol in the minds of the participants or in short Don Fabun in his book The Transfer of Meaning says communication is an event that is experienced internally, purely personal, shared with others. 23 According to Weaver communication is the whole procedure through someone's mind that can affect the thoughts of others. According to Gode, communication is a process that makes something that was originally owned by someone (one's monopoly) to be owned by two or more people. 24 James A.F. Stoner in his book entitled Management, states that communication is a process in which a person tries to provide understanding by moving messages. 25 So that in general communication is the delivery of information, ideas, thoughts, feelings, expertise from the communicator to the communicant to influence the communicant's mind and get responses forth as feedback for communicators.

So that the communicator can measure the success or failure of the message conveyed to the communicant. Communication Theories in general, communication can be divided into several sections, tailored to human needs in interacting, including interpersonal communication, inter-group communication, political communication, mass communication, organizational communication 
and so forth. Based on the method of explanation and the scope of the object of his observations, Littlejohn divided communication theories into two groups. The process of mass communication involves aspects of intra-personal communication, interpersonal communication, group communication and organizational communication. 28 Of the various communication theories that are often used in the teaching and learning process is the theory of interpersonal and group communication. (Barger \& Charles, 2008).

\section{Communication Strategies}

The term communication strategies refers to both linguistic and nonlinguistic strategies that a speaker calls upon to compensate insufficiency in his/her knowledge while communicating. Boxer and Cohen (2004) defined CSs as "a systematic attempt by the speakers or the learners to deliver or give the exact meaning that is not proportionate with the rules of the target language".

\section{Instruments}

The instrument used for collecting data for this study is the observation. The researcher has observed students' use of CSs during their interactions in English classes. (Sabri \& Sunil, 2018)

\section{RESEARCH METHODS}

The research uses a qualitative descriptive research plan. This research draft was chosen because the research plan is capable of describing the teacher's communication strategy during English language learning. This research is expected to describe the communication strategy that the teacher raised. The subject in this study was the teacher of class XI MIA-1 Pencawan. The object of this research is teacher communication strategy in English language learning.

The data collection methods used in this study are documentation methods, interview methods and observation methods. In this research the author uses Nonparticipatory observation methods. This method was chosen because the author wanted to see the natural learning situation performed by the teacher without any intervention from the author. To get a situation that learning naturally the researcher must take the distance with the research subject so that the situation created desired. When observing researchers record specific things or extraordinary things happening in the classroom during the course of learning. The recording was done to see things that the recording device could not record as such as the classroom situation. This method of observation is also accompanied by a recording of activities in the classroom. The use of this recording technique is done to prevent authors ' negligence in recording the communication strategy that the teacher raised. 
After the data is collected, it will then be analyzed by using data analysis. This data analysis is the most important step for getting answers to the problems you want to solve.

\section{RESULTS}

\section{Discussion of the results}

Discussion of the results of this study is focused on the findings of researchers (1) communication strategies that are raised by teachers in learning English (2) Communication strategies most often used by teachers in learning English. The first finding about the communication strategy that was raised by the teacher in learning English. From the observations made by researchers, it appears the teacher raises communication strategies during the learning process. on observations the researchers made observations on class XI MIA-1 and the teacher used Cooperative Strategies.

\section{Understanding Strategy}

Understanding Strategy In the Indonesian Dictionary of the Ministry of Education and Culture defines the strategy is: "careful planning of activities to achieve specific goals." 1 Made Wena, argues that strategy is a way or art of using resources to achieve certain goals. 2 Haitami and Syamsul, stated the strategy is "all means and power to deal with certain targets in certain conditions in order to obtain the expected results to the maximum. 3 In general the strategy has an understanding of the broad outlines of the direction to act in an effort to achieve the specified goals. Associated with teaching and learning, strategies can be interpreted as general patterns of student teacher activities in the realization of teaching and learning activities to achieve the goals outlined. 4 Basic strategies in the educational context can be divided into 4 parts, namely:

1. Identifying and establishing the specifications and qualifications of the behavior and personality changes of students as expected.

2. Choosing a teaching and learning approach system based on people's aspirations and life outlook.

3. Choosing and determining the procedures, methods, and teaching and learning techniques that are considered the most appropriate and effective, so that the teacher can make a handle in carrying out their teaching activities

4. Establishing norms and minimum limits of success or criteria and standards of success, so that teachers can make guidelines in evaluating the results of teaching and learning activities that evaluate the results of teaching and learning activities which will then be used as feedback for improving the overall instructional system concerned. 


\section{Cooperative Learning Strategies}

Cooperative Learning is a strategy used in constructivism learning models. Constructivism learning according to Paul Suparno's assumption is that knowledge is a construction (form) of people who know something itself, constructivism emphasizes the active role of students because knowledge is formed by students actively and not merely passively accepted by the teacher (Suparno, 1997). Cooperative learning is one of the approaches used in constructivist learning models.

Constructivistic learning is an active process of students to build knowledge, not only mental but also physical activity, meaning that through physical activity students' knowledge is actively built based on the process of assimilating experience or material learned with the knowledge the lesson has and it takes place mentally. Thus the essence of this learning is to build an approach. The way of teaching and learning in schools that is based on the theory of constructivism is a way of learning that emphasizes students in shaping their knowledge, while the teacher acts more as a facilitator who helps the student's activeness in shaping his knowledge.

Cooperative learning includes a small group of students who work as a team to solve a problem, complete an assignment, or work towards another common goal. From the description above it can be interpreted that cooperative learning is a teaching model where students learn and work in a small group, they also help each other, discuss and argue with each other in understanding a subject matter and cooperate in working on assignments or worksheets, both in the form of tutorials peer, peer training and correction. So learning can help in minimizing differences in understanding and mastery of the subject matter of each individual student.

\section{Teacher Method Teaching}

\section{Question and Answer Method}

Definition of Question and Answer Method The term teaching method consists of two words namely "method" and "teaching". The method comes from two words namely meta and hodos. Meta means "through", and hodos means "way or way". 1 In the Big Indonesian Dictionary, "method" is "an orderly and well thought out way to achieve intentions." 2 Then methods can be interpreted as roads or ways that must be traversed to achieve certain goals. Some understanding of the method according to some experts, namely:

1. According to Muhibbin Syah in his book "Educational Psychology with a New Approach" is that the Method literally means a way. In general usage, the method is defined as a way of doing an activity or ways of carrying out activities using facts and concepts systematically. 
2. According to Muzayyin Arifin, "Understanding the method is a way, not a step or procedure. The word procedure is more administrative or taxonomic in nature. As if educating or teaching is only interpreted as having implications influence. Then the interdependence between educators students in the process of being together towards specific goals ".

3. According to W.J.S Poerwadarminta, "Method is the" way "which is has been organized and thought out to achieve something mean ". The conclusion of the above meanings namely that the method in general is the right way and fast at doing things, like conveying subjects.

4. According to Muhammad Talib, the method is an orderly method used to carry out a job in order to be achieved a good result as desired. Referring to some experts' understanding above, it can be concluded that the method is an organized or planned method which is used by an educator in delivering or presenting subject matter to students so that learning objectives are determined can be achieved by accompanied by changes in behavior at learners.

\section{Question and answer method}

Question and answer method is a method where the teacher uses or gives questions to students and students answer, or vice versa students ask the teacher and the teacher answers students' questions. (Soetomo, 1993: 150) Question and answer method is a way of presenting lessons in the form of questions that must be answered primarily from teachers to students, but can also from students to teachers (Syaiful Bahri Djamarah 2000: 107). This method is considered better than conventional learning methods namely lecture method. The reason is because this method can stimulate students to think and be creative in the learning process. Question and Answer method can also be used to measure or find out how far the material or teaching material that has been mastered by students.

\section{Steps for Using the Question and Answer Method}

To avoid deviations from the subject matter, the use of the question and answer method must pay attention to the following steps:

1. Formulate clear question and answer objectives in the form of specific goals and focus on student behavior.

2. Looking for reasons for choosing the question and answer method.

3. Define possible questions to be raised.

4. Define possible answers to keep from deviating from the subject matter.

5. Provides the opportunity to ask questions for students. Based on the steps above, the teacher's actions in using the question and answer method must be prepared as carefully as possible in the form of a detailed teaching plan with the following steps: 
State the reasons for using the question and answer method.

1. Prepare questions that fit the specific learning objectives.

2. Summarizing student answers according to specific learning objectives.

3. Give students the opportunity to ask questions that are not yet understood.

4. Giving questions or opportunities to students to ask things that are development or enrichment.

5. Give students the opportunity to answer questions that are relevant and are development or enrichment.

\section{DISCUSSION}

Education in terms of the process is part of communication; in meaning that the process involves two components consisting of humans, namely the teacher as a communicator and students as communicants. While the difference between communication and education lies in its purpose or effect which is expected. Judging from the expected effect, if the purpose of communication general, while the purpose of education is specific. This specificity which in the process of communication gives birth to special terms like information, propaganda, indoctrination, agitation and education.

The purpose of education is to be specific, that is to improve learner knowledge about a matter so that he can master it. This is clearly different from the goals of enlightenment, propaganda, indoctrination, and agitation as mentioned above. The educational objectives will only be achieved if the process is communicative, in the sense that it runs smoothly and effectively. As understood, that in general the process of education or learning is take place in class is face to face (face to face). Because of his group relatively small although basically the pattern of communication between teachers and students in the class including group communication (group communication) but an educator at any time can turn it into communication interpersonal.

Form of communication that is expected to appear in the learning process in class is two-way communication (two ways flow of communication), where educators and students can occupy each other's position both as communicator as well as communicant. The two-way communication process occurs if students are responsive; express opinions or ask questions, asked or not asked. Instead on the part of educators, he must give the widest opportunity for students to open dialogue and creative, innovative and dynamic discussion. Order communication in the process learning is effective, so educators must prepare its strategy thoroughly.

Based on the findings, from eight types of communication strategies, stalling or time gaining strategy appeared to be the most frequent strategies used by the teacher in communicating with the students (36\%). It showed that the 
teacher used many expressions that related to time gaining or fillers in explaining the lesson. The teacher applied them in order to take time to think or to maintain the conversation run smoothly. This findings was relevant with Dornyeim(1995), he discussed stalling or time gaining strategy as 'communication maintenance strategy'. This strategies were not related to the teacher's competence, however it done because the teacher need time to think in the conversation. The second place was taken by comprehension check with the percentage of $14 \%$. The teacher often asked the question to the students in purpose to check their comprehension and to see how far they had understood the material. Non-linguistics means was an effort from teacher to help the students by expressing certain things. Meanwhile, based on the data interview, it can be elaborated that teacher was consciously applied two strategies from thirteen types of CSs.

Those were use non-linguistics means and code switching. Code switching was the way in expressing message that had no words equivalent in English. Juanita (2011) said that someone applied the code switching due to want to emphasize the word in English and the terms by using the equivalent in native language at the same time with the English sentence. Thus, from the discussion above, it can be interpreted that the communication strategies types in the framework were not all employed by the teacher. Nevertheles, the implementation of each startegies used by teacher above was very helpful for the students in understanding the teacher's material and facilitated the teacher in overcoming the problem in communicating with the students during learning and teaching process. The more strategies teacher used, it meant the better conversation or communication among teacher and the students would appeared in the classroom. Commonly, teacher used strategies to keep the conversation going well. The present study indicated that teacher only rely on compensatory strategies in the classroom interaction, since all the eight strategies were categorized into it. Let us turn to non-empirical and empirical studies in support of communication strategy instruction. Those who advocate teaching CS generally make pedagogical recommendations and argue that communication strategy training is desirable in order to develop strategic competence (e.g., Dörnyei \& Thurrell, 1991, 1994; Færch \& Kasper 1983a, 1986; Tarone \& Yule, 1989; Willems, 1987). Færch and Kasper (1986) recommend three specific activity types to practice CS. These are communication games with visual support, without visual support, and monologues. They also recommend increasing students' meta-communicative awareness about the factors that determine appropriate strategy selection through certain analytic tasks, such as audio/video tape analysis of NNS-NS discourse. 


\section{CONCLUSION}

From the three studies above it can be concluded In the learning process still found 15 students from 30 students who have difficulty in communicating, so it is very influential in the participation and achievement of students learning. To solve the problem, it is by using a learning method that requires students to be actively communicating, dare to express opinions. The problem that is examined in this research is how the form of teacher communication with the students occurs

\section{REFERENCES}

Ahmed, S., T., S \& Pawar, S.,V. (2018) Communicative competence in English as a foreign language: Its meaning and the pedagogical considerations for its developmentll. The Creative Launcher, 2 (4), 301-312

Bachman, L., F. (1990). Fundamental Considerations in Language Testing. Oxford University Press

Berger, C., R. (2008). Interpersonal communication. In Wolfgang Donsbach (ed.). The International Encyclopedia of Communication. New York, New York: Wiley-Blackwell.

Boxer \& Cohen (2004), Chapter 12. C. Roever. Difficulty and practicially in tests of interlanguage pragmatics

Canale, M \& Swain, M. (1980). Theoretical bases of communicative approaches to second language teaching and testing. Applied Linguistics, 1(1), 1-47.

Canale, M. (1983). From Communicative Competence to Communicative language Pedagogy. In: C. Jack, Richards \& Richard W. Schmidt (Eds.), Language and Communication. London: Longman.

Carvantes., C \& Roddringuez., R (2012). The use of Communication strategies in the beginner FL classroom. Gist Education and Learning Research Journal, 6 (1),111-128.

Celce-Murcia, M., Dörnyei, Z., \& Thurrell, S. (1995). Communicative competence: A pedagogically motivated model with content specificationsll. Issues in Applied Linguistics, 6(2), 5-35.

Dornyei, Z. (1995). Communication Strategies, Attitude, and Oral Output of EFL Learners: A study of Relation. Open Journal of Modern Linguistics, 6 (5)

Dörnyei, Z \& Thurrell, S. (1991). - Strategic competence and how to teach itll. EFL Journal. 45 (1). 16-23

Dörnyei, Z. \& Scott M. L. (1995). Communication Strategies: An Empirical Analysis With Retrospection. Deseret Language and Linguistic Society Symposium. 21 (1), 137-150. 
Færch, C., \& Kasper, G. (1983). On identifying Communication Strategies in Interlanguage Production. In C. Farch \& G. Kasper (Eds.), Strategies in Interlanguage Communication. London: Longman.

Færch, C., \& Kasper, G. (1986). Strategic competence in foreign language teaching. In G. Kasper (Ed.), Learning, teaching and communication in the foreign language Classroom. Aarhus: Aarhus University Press.

Faucette, P. (2001). A Pedagogical Perspective on Communication Strategies: Benefits of Training and an analysis of English language Teaching Materials. Second Language Studies, 19 (2), 1-40

Juanita, F. D. (2011). Communication Strategies in An English Conversation Class, Widya Warta, 1 (2), 167-178

Majd, Golaleh (2014). Teaching Communication Strategies to EFL Learners and its Impact on Anxiety Level and Motivation: A World. Retrieved from www.esp.world.info .

Putri, L. A. (2013). Communication Strategies in English as a Second Language (ESL) Context. Advances in Language and Literary Studies, 4(1), 129-133

Saraa F., A \& Dina, A., A (2016). Communication Strategies for Teachers and their Students in an EFL Setting. International Journal of Bilingual \& Multilingual Teachers of English, 4 (1)

Sabri, T., S., A \& Sunil V.,P (2018). A study of Communication Strategies Employed by Radfan College EFL Students in their Classroom Interactions. New Academia: An International Journal of English Language, Literature and Literary Theory, 3(3)

Savignon, S. J. (1983). Communicative competence. John Wiley \& Sons, Inc..

Sembiring, Yenita (2019). An Analysis of Students' Vocabulary Ability through Anagram in SMK Sandhy Putra 2 Medan. ELT (English Language Teaching Prima Journal), 1(1) 